\title{
INTERNATIONAL MIGRATION AND NEW MOBILITY TRENDS
}

\author{
E. Abramuszkinová Pavlíková
}

Received: December 17, 2010

\begin{abstract}
ABRAMUSZKINOVÁ PAVLÍKOVÁ, E.: International migration and new mobility trends. Acta univ. agric. et silvic. Mendel. Brun., 2011, LIX, No. 2, pp. 15-20

World migration community covers 3\% of the world population, in Europe it is around $7 \%$ and $4 \%$ in the Czech Republic. Europe is an important target for migration stimulated by the work offer but also by wars and natural disasters. In Western Europe at the end of the 20th century there were 20 millions of foreign migrants and also probably 3-5 million illegal migrants.

Recently, we have faced new trends in international mobility which are different from traditional migration flows. They include mobility of multinational firms employees, mobility of students, pensioners but also mobility of professionals. Specific group under study is foreign migration or mobility of scientists and researchers. There is another phenomena connected with the development of modern technologies which stimulates the mobility in virtual space. Virtual mobility is another form of mobility which is using virtual space for communication, study, work and other aspects of life.

The aim of this paper is to introduce the main trends in international migration including the traditional ones but stressing the new types of international mobility. The focus will be on the current situation in the Czech Republic related to migration.
\end{abstract}

migration, international mobility, foreigners, high skilled professionals, brain drain, virtual mobility

Europe is an important target for migration stimulated by work offer but also by wars and natural disasters. In Western Europe at the end of the 20th century there were 20 millions of foreign migrants and also probably 3-5 million illegal migrants. (Drbohlav, 2001). The assumption of the International Organisation for Migration estimates 230-250 million international migrants by year 2050 (Divinsky, 2005).

World migration community covers $3 \%$ of the world population, in Europe it is around 7\% and 4\% in the Czech Republic (433 305 foreigners in December 2009). The most common nationality groups in the CR include citizens of Ukraine (30\%), Slovakia (17\%), Vietnam (14\%), Russia (7\%) and Poland (5\%).
The Czech Republic used to be a transit country for foreigners but changed into popular destination for migrants. They compose quite heterogenous group in terms of reasons for a stay or motivation for the future (Projekt Výběr).

The latest data on international migrant stock show that estimated number of international migrants at mid-year 2010 for Europe is 69819282 which is 9.5 as a percentage of the population, for Eastern Europe it is 21045866 which is 7.2 as a percentage and for the Czech Republic it is 453041 which is 4.4 as a percentage of the population (Trends in International Migration Stock). ${ }^{1}$

There are different types of migration and new forms of mobility are becoming more frequent.

1 Eastern Europe defined by the United Nations Population Division is composed of the following states: Belarus, Bulgaria, Czech Republic, Hungary, Poland, Republic of Moldova, Romania, Russian Federation, Slovakia and Ukraine (Trends in International Migration Stock). 
Physical mobility is not any more the only way which is opening possibilities for work, studies or communication. A virtual space can be a platform providing wide possibilities for virtual mobility (VM).

\section{METHODS AND RESOURCES}

This paper is based on relevant analytical studies, statistical data and own research results. The research on virtual mobility was directed by author of this text in co-operation with College of Business Doba Maribor, Slovenia and School of Management, Open University of the Netherlands. After a pilot study of five interviews conducted with people involved in VM activities, we have developed a research questionnaire which was sent by email to 3,142 ERASMUS coordinators in February and March 2008. The current list (year 2007) of ERASMUS coordinators was provided by the National Agency. We have received and analysed 198 answers, followed by in-depth interviews with institutions dealing with virtual mobility. Within this qualitative part of the research we addressed six universities: Technical University of Ostrava (VŠB), Palacký University Olomouc (UP), University of Economics, Praha (VŠEE), University of West Bohemia in Pilsen (ZPU), University of Hradec Králové (UHK), Tomas Bata University in Zlín (UTB).

\section{RESULTS AND DISCUSSION}

\section{Overview of the migration situation in the Czech Republic}

In the first half-year of 2010, the population of the Czech Republic increased to 10515 818. Two thirds of the growth result from natural change where the number of live births exceeded the number of deaths by 5.7 thousands. According to the data from the Central Population Register Record of the Ministry of Interior the net migration was 3.3 thousands in the 1st half-year 2010. It was markedly lower than in the same period of 2009 (by 17.1 thousands). The number of immigrants was lower almost by half (by 10.9 thousands to 13.6 thousands), on the contrary the number of emigrants was 2.5 times higher (10.3 thousands against 4.0 thousands a year before). The higher net migration was reached with the citizens of Ukraine (1.6 thousands) and Russia (1.5 thousands), followed by Vietnam and United States (both 0.8 thousands). On the other hand, the significant decrease in the number of citizens from Slovak Republic (by 1.8 thousands), Poland (by 1.5 thousands) and Germany (by 0.7 thousands) was registered. The net international migration of the Czech citizens was balanced (1 092 people migrated so as emigrated) (Pohyb obyvatelstva).

The age structure of foreigners is different as compared to the age stucture of the majority population. Most of the foreigners come to earn their living so the biggest share have age groups in junior pro- ductive age (20-39 years). Over a half (53\%) of all legally residing foreigners in the Czech Republic belonged to this age group by the end of 2008. Very small shares in comparison with the age structure of the CR population can be found among children and those in post-productive age.

The most numerous groups of foreigners according to nationality have been very similar in last years. Nationals of the Ukraine dominate among the foreigners with more than 30\%, followed by citizens of Slovakia (17\%), Vietnam (14\%), Russia (6\%) and Poland (5\%) by the end of 2008 .

The number of legally residing foreigners (i.e. with visas over 90 days or some of the types of residence permits, exluding accredited refugees) exceeded, according to data of Alien Police Service, 430 thousands by the end of 2008 . 93\% out this number resided in the CR one year or more. The proportion of female-foreigners reached about $40 \%$ of the total number of foreigners in 2008 (Foreigners in the Czech Republic).

The latest data (31. 5. 2010) related to the number of foreigners in the Czech Republic mentioned by Alien Police Service declare 426749 foreigners, namelly migrants from Ukraine (128636 people, 30\%), Slovakia (71 392 people, 17\%), Vietnam (60931 people, 14\%), Russia (31 037 people, $7 \%$ ) and Poland (18 572 people, 4\%) (Počet cizinců).

\section{Definition of the foreigner's residence in the $\mathrm{CR}$}

Residence of foreigners in the CR is governed by the Act No. 326/1999 Coll., on the Residence of Foreigners, and partially also by the Act No. 325/1999 Coll., on Asylum, as last amended. According to the law, a foreigner is defined as a physical person, who is not a citizen of the Czech Republic, including a citizen of the European Union. The issue of the foreigner's entry, residence and exit from the CR belongs to competences of the Police of the CR, the Ministry of Interior of the CR, and the Ministry of Foreign Affairs of the CR. A foreigner may reside in the CR temporarily or permenently. The categories of foreigners residing in the CR are as follows:

A. Citizens of member states of the EU, Norway, Switzerland, Island and Liechtenstein, abbreviated as „EU Citizen“ and their dependants

- Citizens of EU Member States registered not having temporary or permanent residence permit and their dependants.

- Citizens of EU Member States and their dependants having temporary residence permit.

- Citizens of EU Member States and their dependants having permanent residence permit.

B. Citizens of countries out of the EU abbreviated as "Citizens of third countries"

- Citizens of third countries staying in the CR for a short time, generally up to 90 days without visa.

- Citizens of third countries staying in the CR based on short/term visa up to 90 days. 
- Citizens of third countries staying in the CR based on visa over 90 days.

- Citizens of third countries having long/term residence permit.

- Citizens of third countries having permanent residence permit.

- Foreigners with current asylum.

C. Foreigners regardless the EU borders

- Registered asylum seekers.

- Foreigners staying in the CR within temporary protection.

- Foreigners staying in the CR illegally.

The demand for a specific type of foreigners in the country have lead the Ministry of Labour and Social Affairs in cooperation with the Czech Ministry of Foreign Affairs and the Czech Ministry of Interior to open the project called Project Selection of Qualified Foreign Workers. It offers to selected qualified workers the opportunity to apply for permanent residence within a shorter period, after one and a half year to highly qualified workers (with university level education) or two and a half years to standard category of qualified workers. Their family members will also be allowed to settle in the CR and to obtain permanent residence there. The pilot stage of the project started in July 2003 as Pilot Project Active Selection of Qualified Foreign Workforce for 5 years. The project is opened now for participants from 51 countries. By July 1st, 2010 there have been 1766 foreigners registered in this project (Project Selection).

\section{Illegal migration}

It is obvious, that the Czech Republic is attractive country for both legal and illegal migrants. The numbers of illegal migrants are quite problematic to estimate and state administration is only one source of these data. Labour offices made together with other bodies of state administration (Alien Police, Czech Customs Administration, labour inspectorates, trade licensing offices, tax authorities) checks of how foreign citizens are employed. In 2008, 24203 foreign workers were checked. From this number, there were 2342 illegally employed foreigners (i.e. $9.7 \%$ of the total persons checked). It is absolutely and relatively more than in 2007 (1 662 i.e. $7.6 \%$ of the number of checked persons) (Foreigners in the Czech Republic).

In relation to the accession of the CR to the Schengen territory it was necessary to basically change the concept of definitions of illegal migration in the CR. From 2008 two basic categories of illegal migration in the CR have been observed. At first, Illegal crossing of the external Schengen border of the CR done by foreigners or the Czech national. At second, Illegal stay as a category where foreigners are revealed in the CR including transit areas at the airports who violate the conditions required by law regulating the stay of foreigners (Foreigners in the Czech Republic).

\section{New Trends}

\section{New types of mobility}

Among traditional forms of migration we can find family migration, asylum seekers migration or work migration. There are also other types of international mobility which are different from traditional migration such as: mobility of multinational employees, temporary mobility of high skilled professionals, mobility of students and researchers or retired people willing to live abroad (Horáková, 2003).

Special group under study nowadays is composed of international migration of scientists and researchers which are offered atractive opportunities in a global world. There is a need for mobility of high skilled professionals from certain areas which are considered as possitive impuls for the development of society and its competitiveness (Kostelecká et al., 2008). On the other hand it opens the issue of brain drain not only for underdeveloped countries but also for European countries after 1989 political changes (Baláž, 2007). The Czech Republic is facing these challenges too which are focused both on Czech professionals but also on foreign professionals in the Czech Republic.

\section{Virtual Space as new oportunity}

Virtual mobility is another form of mobility which is using virtual space for communication, study, work and other aspects of life. In higher education it is quite rapidly developing area offering many opportunities for students. There are several definitions of virtual mobility used in this context.

According to the definition by elearningeurope portal virtual mobility means:

„The use of information and communication technologies (ICT) to obtain the same benefits as one would have with physical mobility but without the need to travel" (Elearningeurope 2010). ICT supported environments include, for example, collaborative workspaces, computer mediated conferencing, live streaming and videoconferencing.

According to the definition by the Being Mobile team: "Virtual mobility is a form of learning which consists of virtual components through an ICT supported learning environment that includes crossborder collaboration with people from different backgrounds and cultures working and studying together, having, as its main purpose, the enhancement of intercultural understanding and the exchange of knowledge" (Being Mobile, 2010).

According to the definition by EADTU and E-move project: "Virtual Mobility is defined as an activity based on a co-operation of - at least two- Higher Education-institutions: two or more institutions agree to offer their students the opportunity to acquire a number of ECTS-points at one of the foreign partner universities or through a joint activity of the partners. The ECTS-points of this international experience will then be counted to the student's degree at his/her home university“ (EADTU, 2010). 
According to EADTU the virtual mobility can be present in three models. The first model is "Virtual Erasmus" - the Virtual Stay Abroad. It offers nonmobile students an international study experience similar to the Erasmus-stay abroad. The focus is on the international exchange of distance teaching course modules in the framework of a study-programme. Students study a module at different university in EU which is counted towards their degree at home.

The second model, the European Virtual Seminar, is a joint course that promotes an international, multidisciplinary dialogue between students on authentic and current issues with the use of modern ICT and the internet to overcome the constraints of place and time. Students participate in heterogenous groups in terms of nationality, discipline, institution and gender.

The third model is the Virtual Campus where students from the partnering institutions are involved to round-off a specific course in their curriculum with a virtual international experience. They complete assignments in a virtual workspace, through collaborating in an international community of students (EADTU, 2010).

The importance of the mobility, including the virtual mobility, is the main focus of the EU Green Book. It promotes the virtual mobility in forms of internet and other electronic means and communications. It can be very helpful not only before the physical mobility by developing contacts, friendships and social networks, but also as a substitute for physical mobility, in cases where stay abroad is not possible (Zelená kniha, 2009). This document opened the discussion which resulted in various statements and recommendations. For example, the Committee of Regions has stressed that the mobility in education area on european level brings huge european added value and can inspire the development of european, national, regional and local programmes. It also supports the idea of european identity and citizenship. It can have possitive influence in fight against xenophobia (Stanovisko Výboru, 2010).
In 2008 we conducted a research in the European Union to explore the issue of the virtual mobility at universities with ERASMUS charters. The goal of this research was to define the virtual mobility (VM) coordinator profile and to design the virtual mobility supervision scheme. VM Coordinator profile describes the required qualities and competences of the staff involved in VM for providing efficient support to VM students during the pre-virtual mobility phase including information, guidance and counseling and during VM to enhance their performance. VM supervision scheme describes the roles, functions and responsibilities of VM coordinators.

The results of the qualitative part reflect the situation in the Czech Republic, where virtual mobility is very new and there is a need for information. Two of the institutions have no experience with VM, while another one was participating in a VM project as a team member but they have no knowledge about the coordinators' experience. The answers of respondents show that there is a need for the position of a Virtual Mobility Coordinator to assure successful participation in virtual mobility. An institutional background of the VMC is prefered with ERASMUS office in cooperation with study department. Direct relations with ERASMUS was strongly recommended.

From the sample of 198 respondents, 9\% of institutions have already been involved in virtual mobility. There were 16 institutions where the position of VMC exists (Project MoreVM).

There have already been positive examples of interuniversity study based on virtual mobility in the Czech Republic, mainly by using eLearning. Since 2005, Faculty of Informatics and Management, University of Hradec Králové, University of West Bohemia, Plzen and Faculty of Management and Economics, Tomas Bata University, Zlín have participated in the project RIUS (Initiation of the Inter-university Study in the Network of Selected Universities in the Czech Republic). Another project EVENE was created as a network of traditional European higher education institutions operating in the field of economics and management (Poulová et al., 2007).

\section{SUMMARY}

Europe is an important target for migration stimulated by work offer but also by wars and natural disasters. In Western Europe at the end of the 20th century there were 20 millions of foreign migrants and also probably 3-5 million illegal migrants. The assumption of the International Organisation for Migration estimates 230-250 million international migrants by year 2050. World migration community covers $3 \%$ of the world population, in Europe it is around $7 \%$ and $4 \%$ in the Czech Republic. The most common nationality groups in the CR include citizens of Ukraine (30\%), Slovakia (17\%), Vietnam (14\%), Russia (7\%) and Poland (5\%). The Czech Republic used to be a transit country for foreigners but changed into popular destination for migrants. They compose quite heterogenous group in terms of reasons for a stay or motivation for the future.

Recently, we have faced new trends in international mobility which are different from traditional migration flows. They include mobility of multinational firms' employees, mobility of students, pensioners but also mobility of professionals. Specific group under study is foreign migration or mobility 
of scientists and researchers. There is another phenomena connected with the development of modern technologies which stimulates the mobility in a virtual space. Virtual mobility is another form of mobility which is using virtual space for communication, study, work and other aspects of life.

The aim of this paper is to introduce the main trends in international migration including the traditional ones but stressing the new types of international mobility. The focus is on the current situation in the Czech Republic related to migration.

In the first half-year of 2010, the population of the Czech Republic increased to 10515818 . The international migration ballance was positive at the level of 3.3 thousands. The age structure of foreigners is different as compared to the age stucture of the majority population. Most of the foreigners come to earn their living so the biggest share have age groups in junior productive age (20-39 years). The most numerous groups of foreigners according to nationality have been very similar in last years: migrants from Ukraine (30\%), Slovakia (17\%), Vietnam (14\%), Russia (7\%) and Poland (4\%) in May 2010.

According to the law, a foreigner is defined as a physical person, who is not a citizen of the Czech Republic, including a citizen of the European Union. The categories of foreigners residing in the CR are as follows:

1. Citizens of member states of the EU, Norway, Switzerland, Island and Liechtenstein, abbreviated as „EU Citizen“ and their dependants.

2. Citizens of countries out of the EU abbreviated as „Citizens of third countries“.

3. Foreigners regardless the EU borders.

In relation to the accession of the CR to the Schengen territory it was necessary to basically change the concept of definitions of illegal migration in the CR. From 2008 two basic categories of illegal migration in the CR have been observed: an Illegal crossing of the external Schengen border of the CR and an Illegal stay.

There are new trends in migration movements which we can face also in the Czech Republic. One example is the Project Selection of Qualified Foreign Workers which offers to selected qualified workers and their families the opportunity to apply for permanent residence within a shorter period. The project is now opened for participants from $5 \mathrm{l}$ countries and is implemented by the Ministry of Labour and Social Affairs in cooperation with the Czech Ministry of Foreign Affairs and the Czech Ministry of Interior.

Among traditional forms of migration we can find family migration, asylum seekers migration or work migration. There are also other types of international mobility which are different from traditional migration such as: mobility of multinational employees, temporary mobility of high skilled professionals, mobility of students and researchers or retired people willing to live abroad. Special group under study nowadays is composed of international migration of scientists and researchers which are offered atractive opportunities in a global world. There is a need for mobility of high skilled professionals from certain areas which are considered as possitive impuls for the development of society and its competitiveness. On the other hand it opens the issue of brain drain not only for underdeveloped countries but also for European countries after 1989 political changes. The Czech Republic is facing these challenges too which are focused both on Czech professionals but also on foreign professionals in the Czech Republic.

Virtual mobility is another form of mobility which is using virtual space for communication, study, work and other aspects of life. In 2008 we conducted a research in the European Union to explore the issue of the virtual mobility at universities with ERASMUS charters. The research on virtual mobility was directed by author of this text with partner institutions in the Netherlands and Slovenia. European ERASMUS coordinators were contacted by email and on/line questionnaire. Feedback from 198 European institutions together with qualitative interviews provided information about the current state of virtual mobility coordination. The results reflect the situation in the Czech Republic, where virtual mobility is very new and there is a need for information. The answers of respondents show that there is a need for the position of a Virtual Mobility Coordinator to assure successful participation in virtual mobility. An institutional background of the VMC is prefered with ERASMUS office in cooperation with the study department. Direct relations with ERASMUS was strongly recommended. The Czech Republic is not only a transit country but more often a popular destination for migrants, not only in traditional forms of migration. This paper tried to open current trends in international mobility incorporating also the issue of virtual mobility. 


\section{REFERENCES}

BALÁŽ, V., 2007: How Much Does Brain Drain Cost? In: Visegrad Moves. On Migration in Central Europe. Praha: Multikulturní centrum.

Being Mobile, 2010: European cooperation in education through Virtual Mobility. A best-practice manual. [cit. 2010-10-09]. Cited from http://www. being-mobile.net.

DIVINSKÝ, B., 2005: Zahraničná migrácia v Slovenskej republike. Stav, trendy, spoločenské súvislosti. Bratislava.

DRBOHLAV, D., 2001: Mezinárodní migrace obyvatelstva - pohyb i pobyt (Alenky v kraji divů). In Šišková, T. (ed.), Menšiny a migranti v České republice. My a oni v multikulturní spolećnosti 21. století. Praha: Portál.

EADTU, 2010: Guide to Virtual Mobility (EADTU Annual Conference 2007, Lisbon, Portugal). [cit. 2010-09-03]. Cited from http://145.20.178.4/ Portals/0/documents/The_Guide_to_Virtual_ Mobility.pdf Elearningeurope Portal 2010. [cit. 2010-11-10]. Cited from http://elearningeuropa. info.

Foreigners in the Czech Republic, 2009: Czech Statistical Office. [cit. 2010-11-05]. Cited from http:// www.czso.cz/csu/cizinci.nsf.

HORÁKOVÁ, M., 2003: Mezinárodní migrace a migrace cizí pracovni sily. Praha: VÚPSV.

KOSTELECKÁ, Y., BERNARD, J., PATOČKOVÁ, V., KOSTELECKÝ, T., 2008: How to Turn Brain Drain into Brain Gain. Policies to Support Return of Researchers and Scientists to Their Home Countries. Praha: SOÚ.

Počet cizincu. Czech Statistical Office. [cit. 2010-1107]. Cited from http://www.czsu.cz/csu/cizinci. nsf/kapitola/ciz_pocet_cizincu.
Pohyb obyvatelstva. Rychlá informace. 13. 9. 2010. Počet obyvatel se zvýšil. [cit. 2010-09-20]. Cited from http://www.czsu.cz/csu/csu.nsf/informace/ coby091310.doc.

POULOVÁ, P., HÁN, J., ZIMOLA, B., 2007: Interuniverzitní studium a virtuální mobility. In: Motyčka, A. (ed.), Informatika XX/2007. Sborník abstrakti̊ z mezinárodní odborné pedagogicky zamérené konference. Brno: Konvoj.

Project MoreVM. [cit. 2010-10-05]. Cited from http:// morevm.org/project.

Project Selection of Qualified Foreign Workers. [cit. 2010-11-01]. Cited from http://www.imigracecz. org.

Projekt Výbèr kvalifikovaných zahraničních pracovníkü. [cit. 2009-12-15]. Cited from http://www.imigracecz.org/.

Stanovisko Výboru regionui. Zelená kniha. Podpora mobility mladých lidí ve vzdělávání. Ưřední věstník Evropské unie, 1.7.2010: 2010/C175/08. [cit. 201101-30]. Cited from http://eur-lex.europa.eu/LexUriServ/LexUriServ.do?uri=OJ:C:2010:175:0031:0 034:CS:PDF.

Trends in International Migrant Stock: The 2008 Revision. (2009) Population Division of the Department of Economic and Social Affairs of the United Nations Secretariat. New York: United Nations Population Division. [cit. 2010-11-15]. Cited from http://esa. un.org/migration/p2k0data.asp.

Zelená kniha. Podpora mobility mladých lidí ve vzdělávání: 2009. Komise Evropských společenství. Brusel. [cit. 2011-01-29]. Cited from http://ec.europa.eu/education/lifelong-learningpolicy/doc/mobility/com329_cs.pdf. 